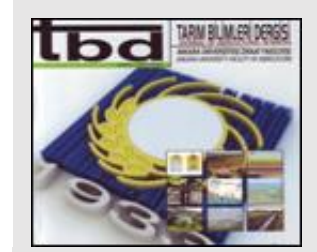

Tarım Bilimleri Dergisi Tar. Bil. Der.

Dergi web sayfası: www.agri.ankara.edu.tr/dergi
Journal of Agricultural Sciences

Journal homepage: www.agri.ankara.edu.tr/journal

\title{
Appraisal of Linear Type Traits in Simmental Cows Reared on High Altitude of Eastern Turkey
}

\author{
Olcay GULER ${ }^{\mathrm{a}}$, Abdulkerim DILER ${ }^{\mathrm{b}}$, Mete YANAR ${ }^{\mathrm{c}}$, Recep AYDIN ${ }^{\mathrm{c}}$, Ridvan KOCYIGIT ${ }^{\mathrm{c}}$

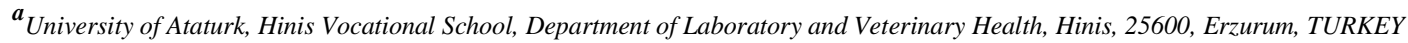

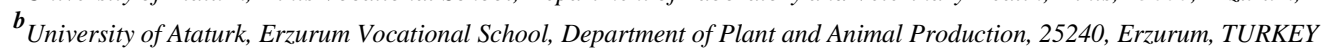

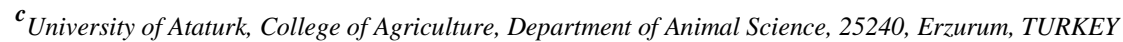

\author{
ARTICLE INFO \\ Research Article \\ Corresponding Author: Mete YANAR, E-mail: mtyanar@gmail.com, Tel: +90 (442) 2360958 \\ Received: 26 February 2019, Received in Revised Form: 09 May 2019, Accepted: 13 May 2019
}

\section{AUTHORS ORCID ID:}

(Olcay GULER: 0000-0001-8849-8680), (Abdulkerim DILER: 0000-0001-7958-6179), (Mete YANAR: 0000-0002-5311-5675), (Recep AYDIN: 0000-0001-9319-9319), (Ridvan KOCYIGIT: 0000-0001-9979-0804)

\begin{abstract}
The study was carried out to investigate the magnitude of nongenetic factors influencing linear type traits and to estimate phenotypic correlations among these traits in Simmental cows. The 16 linear type traits were recorded for 148 Simmental cows reared in a private farm in Eastern Turkey. A statistical model used in this research included fixed effects of stage of lactation, parity, season at time of classification and classifier. The age at time of classification was included to the statistical model as co-variable. Parity, stage of
\end{abstract}

lactation, season at time of classification and classifier effect was significant $(\mathrm{P}<0.01-0.05)$ for chest width, angularity, teat placement side view, body depth. Parity, stage of lactation, season at time of classification effect was significant $(\mathrm{P}<0.01-0.05)$ for rear leg rear view, rump width, suspensory ligament and udder depth. Linear and quadratic effects of age at time of classification were also significant ( $\mathrm{P}<0.01-0.05)$ for rump width, rump angle, teat placement rear view, foot angle, suspensory ligament and udder depth. Phenotypic correlations among linear type traits were in low to medium range.

Keywords: Linear type traits; Non-genetic factors; Phenotypic correlations; Simmental

\section{Introduction}

C Ankara Üniversitesi Ziraat Fakültesi

The linear type traits are defined as the body parts of a dairy cow, which make her capable to produce milk and those traits which are directly or indirectly related with each other (Dubey 2010). Linear type traits are considered as the basis of all systems for describing the dairy cattle, and serve as the basis of all modern type classification systems. These traits allow us to describe the cow in detail based on a defined scale for each trait. Linear evaluation is based on measurements of individual type traits in place of opinions, and defines the degree of trait not the desirability (ICAR 2014). The system allows more objective and accurate assessment of dairy cattle than traditional desirability-based schemes (Alphonsus et al 2011).

In recent years, emphasis has altered from subjective grading methods for assessing dairy cows to more objective methods such as linear type traits (Essien \& Adesope 2003). Linear type traits especially become important when making reproduction and selection decisions in dairy cows (Schneider et al 2003). They may also have influences directly and indirectly on milk production, longevity and culling decisions (Zavadilova \& Stipkova 2012), and might be utilized to define the dairyness of a cow (Dubey et al 2014). Since the linear type traits can be determined in early life of cattle and could have moderate genetic correlations with milk yield and longevity traits, they might be used as indirect predictors of these production traits (Bohlouli et al 2015). In addition, results of several research indicated 
usefulness of linear type traits as predictors of body weight (Berry et al 2004), health (Juozaitiene et al 2006), and fertility (Harris 2015) in dairy cows.

Environmental factors might be defined as factors with measurable effects for example, stage of lactation, age of cow, calving year, season, parity, etc., and factors with non-measurable effects such as parasitic infestations, infectious diseases etc. The measurable effects can be used in preparing the livestock improvement programs in future (Javed et al 2013). In these programs, performance records of animals have to be standardized for the non-genetic sources of variation to decrease known environmental differences among animals (Tuzemen et al 2013).

Parity, classifier, season at time of classification, stage of lactation and age of the cow at time of classification are considered as the most significant environmental factors, although several non-genetic factors affecting linear type traits were pointed out by Esteves et al (2004), Mazza et al (2013), Dubey et al (2014). These factors have to be adjusted in the model, or by pre-adjustment of these records for breeding value estimation of linear type traits (Veerkamp et al 2002). Therefore, the magnitude of the non-genetic factors is required for more accurate appraisal of the type traits (Khan \& Khan 2015). The linear type trait scoring and determination of the effects of non-genetic factors on these traits of Simmental cows reared on the mountainous region of Eastern Turkey has not been made in the past. Therefore, the current study was conducted in order to investigate the quantification of non-genetic factors influencing linear type traits of Simmental cows.

\section{Material and Methods}

In this research, a total of 897 linear type scores obtained from 148 Simmental cows reared at a private farm in Erzurum, Eastern Turkey were used. Erzurum province has mountainous geographical conditions, and its altitude is about 2000 meter above sea level. Especially temperature in winter season is around minus $5-10{ }^{\circ} \mathrm{C}$ and it snows a lot.

In this private farm, Simmental cattle were housed in a free-stall closed barn. They were milked twice a day and average lactation length of the cows is 305 days. Artificial insemination is practised in this farm, and the cows give birth on winter, spring and fall seasons. Calves are weaned about 2 months of age, and they are offered $4 \mathrm{~kg} \mathrm{day}^{-1}$ whole milk in 2 times in a day (in the morning and in the evening).

Linear scoring was made according to the guidelines of International Committee for Animal Recording by 3 classifiers (ICAR 2014). Sixteen type traits were scored on a scale of 1-9, and the definitions of the linear type traits are tabulated in Table 1. Only lactating cows were scored in the afternoon prior to evening milking. Data concerning age of cow at time of classification, parity, days in milk were provided from records available in the farm. Days in milk were classified into 6 stages of lactation that were 1 ( $<2$ months), 2 ( $2-<4$ months), 3 ( $4-<6$ months), 4 ( $6-<8$ months), 5 (8$<10$ months), 6 (>10 months). Seasons at time of classification were divided into 4 classes [1: Winter (December, January, February), 2: Spring (March, April, May), 3: Summer (June, July, August), 4: Fall (September, October, November)].

Table 1- Definition of the Linear Type Traits

\begin{tabular}{|c|c|c|c|}
\hline \multirow{2}{*}{ Traits } & \multicolumn{3}{|c|}{ Scores } \\
\hline & $1-3$ & $4-6$ & $7-9$ \\
\hline Chest width & Narrow & Intermediate & Wide \\
\hline Body depth & Shallow & Intermediate & Deep \\
\hline Angularity & Lacks angularity & Intermediate & Very angular \\
\hline Rump angle & High pins & Intermediate & Extreme slope \\
\hline Rump width & Narrow & Intermediate & Wide \\
\hline Rear legs side view & Straight & Intermediate & Sickle \\
\hline Rear legs rear view & Extreme toe out & Intermediate & Parallel feet \\
\hline Foot angle & Very low angle & Intermediate & Very steep \\
\hline Fore udder attachment & Weak and loose & Intermediate & Extremely strong and tight \\
\hline Rear udder attachment height & Very low & Intermediate & High \\
\hline Central ligament & Outside of quarter & Intermediate & Inside of quarter \\
\hline Udder depth & Below hock & Intermediate & Shallow \\
\hline Teat placement rear view & Outside of quarter & Middle of quarter & Inside of quarter \\
\hline Teat placement side view & Close & Intermediate & Apart \\
\hline Teat length & Short & Intermediate & Long \\
\hline Rear udder attachment width & Narrow & Intermediate & Wide \\
\hline
\end{tabular}


Statistical analyses were carried out by using the GLM of SPSS statistics program, and all data were analysed by using univariate analysis of variance in general linear model of SPSS (SPSS 2004). Different combination of fixed effects and interactions were included into the mathematical model. Since interaction effects were not significant in the initial analysis, they were excluded from the ultimate model. Fixed effects included in the final model are scorer, parity, season at time of classification and stage of lactation. The linear and quadratic effects of age at time of classification were also added on the statistical model as covariant. The method of LSD multiple range test was used for comparison among subclass means. Correlations among the linear type traits were also calculated by using SPSS program (SPSS 2004).

\section{Results and Discussion}

Least-squares means with their standard errors and level of significance of type traits of the dairy cows for different parities are presented in Table 2 and 3. The analysis of variance demonstrated that the influence of parity was significant $(\mathrm{P}<0.01)$ on all linear type traits except for foot angle, fore udder attachment, rear udder attachment height, teat placement rear view. This finding was compatible with results of Parveen (2008), Marinov et al (2015) who also observed significant effect of parity on large number of type traits in Sahiwal and Black-and-White cattle respectively. In the current study, significant parity effects on chest width, body depth, angularity, rear leg rear view, rear udder attachment width, teat length, suspensory ligament and udder depth were also in agreement to results of Viji et al (1990), Khan \& Khan (2015). Additionally, while Liu et al (2014) pointed out significant parity differences for udder depth, fore udder attachment, rear udder height and rear udder width of Chinese Holsteins, Petkov \& Stoyanova (2006) reported significant effect of various parities on the fore udder attachment, udder depth, teat length, udder balance and rear legs-rear view in Black-and-White cows in Bulgaria.

Table 2- Least-squares means along with their standard errors and level of significance of linearly scored type traits

\begin{tabular}{|c|c|c|c|c|c|c|c|c|c|}
\hline & & Chest width & Body depth & Angularity & Foot angle & $\begin{array}{l}\text { Rear leg } \\
\text { side view }\end{array}$ & $\begin{array}{l}\text { Rear leg } \\
\text { rear view }\end{array}$ & $\begin{array}{l}\text { Rump } \\
\text { angle }\end{array}$ & $\begin{array}{l}\text { Rump } \\
\text { width }\end{array}$ \\
\hline & $N$ & $\bar{X} \pm S_{\bar{x}}$ & $\bar{X} \pm S_{\bar{x}}$ & $\bar{X} \pm S_{\bar{x}}$ & $\bar{X} \pm S_{\bar{x}}$ & $\bar{X} \pm S_{\bar{x}}$ & $\bar{X} \pm S_{\bar{x}}$ & $\bar{X} \pm S_{\bar{x}}$ & $\bar{X} \pm S_{\bar{x}}$ \\
\hline General & & $5.4 \pm 0.1$ & $6.4 \pm 0.1$ & $5.0 \pm 0.2$ & $5.0 \pm 0.2$ & $4.6 \pm 0.2$ & $3.9 \pm 0.1$ & $6.0 \pm 0.1$ & $4.9 \pm 0.1$ \\
\hline Parity & & $* *$ & $* *$ & $* *$ & ns & $* *$ & $* *$ & $* *$ & $* *$ \\
\hline 1 & 582 & $5.7 \pm 0.1^{\mathrm{a}}$ & $5.8 \pm 0.1^{\mathrm{b}}$ & $5.7 \pm 0.1^{\mathrm{a}}$ & $5.0 \pm 0.1$ & $4.1 \pm 0.1^{\mathrm{b}}$ & $3.9 \pm 0.1^{\mathrm{b}}$ & $5.6 \pm 0.1^{\mathrm{a}}$ & $4.8 \pm 0.1^{\mathrm{b}}$ \\
\hline 2 & 156 & $5.0 \pm 0.1^{\mathrm{bc}}$ & $6.8 \pm 0.1^{\mathrm{a}}$ & $4.2 \pm 0.2^{\mathrm{b}}$ & $5.2 \pm 0.2$ & $5.2 \pm 0.2^{\mathrm{a}}$ & $4.2 \pm 0.1^{\mathrm{a}}$ & $6.1 \pm 0.1^{\mathrm{ab}}$ & $5.2 \pm 0.1^{\mathrm{a}}$ \\
\hline 3 & 126 & $5.2 \pm 0.1^{\mathrm{bc}}$ & $6.4 \pm 0.1^{\mathrm{ab}}$ & $5.0 \pm 0.2^{\mathrm{a}}$ & $5.3 \pm 0.2$ & $4.4 \pm 0.2^{\mathrm{b}}$ & $4.1 \pm 0.1^{\mathrm{a}}$ & $5.9 \pm 0.1^{\mathrm{ab}}$ & $4.8 \pm 0.1^{\mathrm{b}}$ \\
\hline 4 & 33 & $5.5 \pm 0.5^{\mathrm{ab}}$ & $6.5 \pm 0.4^{\mathrm{ab}}$ & $4.9 \pm 0.6^{\mathrm{ab}}$ & $4.4 \pm 0.6$ & $4.7 \pm 0.6^{\mathrm{ab}}$ & $3.5 \pm 0.4^{\mathrm{b}}$ & $6.2 \pm 0.4^{\mathrm{a}}$ & $4.7 \pm 0.4^{\mathrm{c}}$ \\
\hline Stage of lactation & & $* *$ & $* *$ & $* *$ & ns & $* *$ & $*$ & $* *$ & $* *$ \\
\hline 1 & 69 & $4.9 \pm 0.2^{\mathrm{b}}$ & $5.6 \pm 0.2^{b}$ & $5.8 \pm 0.2^{\mathrm{a}}$ & $5.2 \pm 0.2$ & $4.7 \pm 0.2^{\mathrm{a}}$ & $3.7 \pm 0.2^{\mathrm{b}}$ & $6.0 \pm 0.2^{\mathrm{ab}}$ & $4.4 \pm 0.2^{\mathrm{b}}$ \\
\hline 2 & 165 & $5.4 \pm 0.2^{\mathrm{a}}$ & $6.6 \pm 0.1^{\mathrm{a}}$ & $4.8 \pm 0.2^{\mathrm{bc}}$ & $5.0 \pm 0.2$ & $4.3 \pm 0.2^{\mathrm{b}}$ & $4.0 \pm 0.1^{\mathrm{ab}}$ & $6.0 \pm 0.1^{\mathrm{ab}}$ & $4.6 \pm 0.1^{\mathrm{b}}$ \\
\hline 3 & 180 & $5.6 \pm 0.1^{\mathrm{a}}$ & $6.7 \pm 0.1^{\mathrm{a}}$ & $4.8 \pm 0.2^{\mathrm{bc}}$ & $4.9 \pm 0.2$ & $4.8 \pm 0.2^{\mathrm{a}}$ & $4.1 \pm 0.1^{\mathrm{a}}$ & $5.9 \pm 0.1^{\mathrm{b}}$ & $4.9 \pm 0.1^{\mathrm{b}}$ \\
\hline 4 & 207 & $5.5 \pm 0.1^{\mathrm{a}}$ & $6.5 \pm 0.1^{\mathrm{a}}$ & $5.0 \pm 0.2^{\mathrm{b}}$ & $4.8 \pm 0.2$ & $4.9 \pm 0.2^{\mathrm{a}}$ & $4.0 \pm 0.1^{\mathrm{a}}$ & $5.9 \pm 0.1^{\mathrm{b}}$ & $5.1 \pm 0.1^{\mathrm{ab}}$ \\
\hline 5 & 180 & $5.4 \pm 0.2^{\mathrm{a}}$ & $6.4 \pm 0.1^{\mathrm{a}}$ & $4.8 \pm 0.2^{\mathrm{bc}}$ & $5.0 \pm 0.2$ & $4.7 \pm 0.2^{\mathrm{a}}$ & $4.0 \pm 0.1^{\mathrm{ab}}$ & $6.2 \pm 0.1^{\mathrm{a}}$ & $5.0 \pm 0.1^{\mathrm{b}}$ \\
\hline 6 & 96 & $5.4 \pm 0.2^{\mathrm{a}}$ & $6.6 \pm 0.2^{\mathrm{a}}$ & $4.8 \pm 0.2^{\mathrm{bc}}$ & $4.9 \pm 0.2$ & $4.2 \pm 0.2^{\mathrm{c}}$ & $3.7 \pm 0.2^{\mathrm{c}}$ & $5.8 \pm 0.2^{\mathrm{b}}$ & $5.3 \pm 0.2^{\mathrm{a}}$ \\
\hline $\begin{array}{l}\text { Season at time } \\
\text { of classification }\end{array}$ & & $* *$ & $* *$ & $* *$ & $* *$ & $* *$ & $* *$ & ns & $* *$ \\
\hline 1 & 366 & $4.9 \pm 0.1^{\mathrm{b}}$ & $6.0 \pm 0.1^{\mathrm{a}}$ & $5.0 \pm 0.2^{\mathrm{b}}$ & $5.1 \pm 0.2^{\mathrm{a}}$ & $5.0 \pm 0.2^{\mathrm{a}}$ & $4.5 \pm 0.1^{\mathrm{a}}$ & $5.8 \pm 0.1^{\mathrm{b}}$ & $5.0 \pm 0.1^{\mathrm{b}}$ \\
\hline 2 & 243 & $5.5 \pm 0.2^{\mathrm{a}}$ & $7.1 \pm 0.2^{\mathrm{c}}$ & $3.7 \pm 0.2^{\mathrm{c}}$ & $3.9 \pm 0.2^{\mathrm{b}}$ & $5.1 \pm 0.2^{\mathrm{a}}$ & $4.2 \pm 0.2^{\mathrm{ab}}$ & $6.1 \pm 0.2^{\mathrm{a}}$ & $4.8 \pm 0.2^{\mathrm{bc}}$ \\
\hline 3 & 33 & $5.4 \pm 0.3^{\mathrm{ab}}$ & $5.7 \pm 0.2^{\mathrm{a}}$ & $6.2 \pm 0.3^{\mathrm{a}}$ & $5.6 \pm 0.3^{a}$ & $4.0 \pm 0.3^{\mathrm{b}}$ & $2.7 \pm 0.2^{\mathrm{c}}$ & $6.0 \pm 0.2^{\mathrm{ab}}$ & $4.5 \pm 0.2^{\mathrm{c}}$ \\
\hline 4 & 255 & $5.7 \pm 0.2^{\mathrm{a}}$ & $6.8 \pm 0.1^{\mathrm{b}}$ & $5.0 \pm 0.2^{\mathrm{b}}$ & $5.3 \pm 0.2^{\mathrm{a}}$ & $4.3 \pm 0.2^{\mathrm{b}}$ & $4.3 \pm 0.1^{\mathrm{ab}}$ & $5.9 \pm 0.1^{\mathrm{ab}}$ & $5.2 \pm 0.1^{\mathrm{a}}$ \\
\hline Classifier & & $* *$ & $* *$ & $* *$ & ns & ns & ns & ns & ns \\
\hline 1 & 299 & $5.2 \pm 0.1^{\mathrm{b}}$ & $6.2 \pm 0.1^{\mathrm{b}}$ & $4.8 \pm 0.2^{\mathrm{a}}$ & $4.9 \pm 0.2$ & $4.5 \pm 0.2$ & $3.9 \pm 0.1$ & $6.0 \pm 0.1$ & $4.8 \pm 0.1$ \\
\hline 2 & 299 & $5.4 \pm 0.1^{\mathrm{ab}}$ & $6.5 \pm 0.1^{\mathrm{a}}$ & $4.9 \pm 0.2^{\mathrm{a}}$ & $5.0 \pm 0.2$ & $4.7 \pm 0.2$ & $3.9 \pm 0.1$ & $6.0 \pm 0.1$ & $4.8 \pm 0.1$ \\
\hline 3 & 299 & $5.5 \pm 0.1^{\mathrm{a}}$ & $6.4 \pm 0.1^{\mathrm{a}}$ & $5.2 \pm 0.2^{\mathrm{b}}$ & $5.0 \pm 0.2$ & $4.6 \pm 0.2$ & $4.0 \pm 0.1$ & $5.9 \pm 0.1$ & $4.9 \pm 0.1$ \\
\hline \multicolumn{10}{|l|}{$\begin{array}{l}\text { Age at time of } \\
\text { classification }\end{array}$} \\
\hline Linear & & ns & ns & ns & $*$ & ns & ns & $* *$ & $*$ \\
\hline $\mathrm{b}_{1}$ & & -0.067 & -0.053 & 0.101 & 0.090 & -0.007 & 0.120 & 0.091 & 0.083 \\
\hline Quadratic & & ns & ns & ns & $*$ & ns & ns & $* *$ & ns \\
\hline $\mathrm{b}_{2}$ & & 0.001 & 0.000 & -0.001 & -0.001 & 0.00007 & -0.001 & -0.001 & -0.001 \\
\hline
\end{tabular}

$* *, \mathrm{P}<0.01 ; *, \mathrm{P}<0.05 ;$ ns, non-significant 
A significant decrease in linear score for body depth, rear leg side view in second parity and a slight insignificant increase was observed in third parity (Table 2). The linear score also increased along with progress in stage of lactation for body depth, rear leg side view, fore udder attachment, teat length, teat placement rear view (Table 2 and 3). On the other hand, significant parity effect for a decrease in linear type score was observed for rear udder attachment height, suspensory ligament (Table 3). Findings of the present study were consistent with results from previous studies (Yanar 1999; Marinov et al 2015).

Table 3- Least-squares means along with their standard errors and level of significance of linearly scored type traits

\begin{tabular}{|c|c|c|c|c|c|c|c|c|c|}
\hline & & $\begin{array}{l}\text { Fore } \\
\text { udder } \\
\text { attachment }\end{array}$ & $\begin{array}{l}\text { Rear } \\
\text { udder } \\
\text { attachment } \\
\text { width }\end{array}$ & $\begin{array}{l}\text { Rear } \\
\text { udder } \\
\text { attachment } \\
\text { height }\end{array}$ & $\begin{array}{l}\text { Teat } \\
\text { placement } \\
\text { rear view }\end{array}$ & $\begin{array}{l}\text { Teat } \\
\text { placement } \\
\text { side view }\end{array}$ & $\begin{array}{l}\text { Teat } \\
\text { length }\end{array}$ & $\begin{array}{l}\text { Suspensory } \\
\text { ligament }\end{array}$ & $\begin{array}{l}\text { Udder } \\
\text { depth }\end{array}$ \\
\hline & $N$ & $X \pm S_{\bar{x}}$ & $\bar{X} \pm S_{\bar{x}}$ & $\bar{X} \pm S_{\bar{x}}$ & $X \pm S_{\bar{x}}$ & $X \pm S_{\bar{x}}$ & $X \pm S_{\bar{x}}$ & $X \pm S_{\bar{x}}$ & $X \pm S_{\bar{x}}$ \\
\hline General & & $4.2 \pm 0.2$ & $4.8 \pm 0.8$ & $4.6 \pm 0.2$ & $5.1 \pm 0.2$ & $5.0 \pm 0.2$ & $6.0 \pm 0.2$ & $5.9 \pm 0.1$ & $5.5 \pm 0.1$ \\
\hline Parity & & ns & $* *$ & ns & ns & $* *$ & $* *$ & $* *$ & $* *$ \\
\hline 1 & 582 & $3.7 \pm 0.1$ & $5.0 \pm 0.1^{\mathrm{a}}$ & $4.9 \pm 0.1$ & $5.0 \pm 0.1$ & $5.6 \pm 0.1^{\mathrm{a}}$ & $5.5 \pm 0.1^{\mathrm{c}}$ & $6.4 \pm 0.1^{\mathrm{a}}$ & $4.9 \pm 0.1^{b}$ \\
\hline 2 & 156 & $3.9 \pm 0.2$ & $4.1 \pm 0.2^{b}$ & $4.8 \pm 0.1$ & $5.0 \pm 0.2$ & $4.9 \pm 0.2^{\mathrm{b}}$ & $5.7 \pm 0.1^{\mathrm{bc}}$ & $6.4 \pm 0.1^{\mathrm{a}}$ & $5.9 \pm 0.1^{\mathrm{a}}$ \\
\hline 3 & 126 & $4.4 \pm 0.2$ & $4.2 \pm 0.2^{\mathrm{b}}$ & $4.8 \pm 0.2$ & $5.0 \pm 0.2$ & $4.6 \pm 0.2^{b}$ & $5.9 \pm 0.1^{\mathrm{b}}$ & $5.8 \pm 0.1^{b}$ & $5.4 \pm 0.2^{\mathrm{b}}$ \\
\hline 4 & 33 & $5.0 \pm 0.7$ & $5.8 \pm 0.7^{\mathrm{a}}$ & $3.9 \pm 0.6$ & $5.4 \pm 0.6$ & $4.9 \pm 0.6^{\mathrm{ab}}$ & $6.9 \pm 0.1^{\mathrm{a}}$ & $5.2 \pm 0.5^{\mathrm{b}}$ & $5.8 \pm 0.5^{\mathrm{ab}}$ \\
\hline Stage of lactation & & $* *$ & ns & ** & ns & $* *$ & ns & $* *$ & $* *$ \\
\hline 1 & 69 & $5.1 \pm 0.3^{\mathrm{a}}$ & $4.7 \pm 0.3$ & $5.1 \pm 0.2^{\mathrm{a}}$ & $5.5 \pm 0.2$ & $4.7 \pm 0.2^{\mathrm{c}}$ & $5.8 \pm 0.2$ & $5.5 \pm 0.2^{\mathrm{c}}$ & $6.0 \pm 0.2^{\mathrm{a}}$ \\
\hline 2 & 165 & $3.4 \pm 0.2^{\mathrm{b}}$ & $4.9 \pm 0.2$ & $4.5 \pm 0.2^{b c}$ & $5.2 \pm 0.2$ & $5.3 \pm 0.2^{\mathrm{a}}$ & $6.1 \pm 0.1$ & $5.6 \pm 0.2^{\mathrm{c}}$ & $5.2 \pm 0.2^{\mathrm{d}}$ \\
\hline 3 & 180 & $3.6 \pm 0.2^{b}$ & $4.9 \pm 0.2$ & $4.8 \pm 0.2^{\mathrm{ab}}$ & $5.0 \pm 0.2$ & $5.1 \pm 0.2^{\mathrm{ab}}$ & $6.0 \pm 0.1$ & $6.2 \pm 0.1^{\mathrm{a}}$ & $5.1 \pm 0.2^{\mathrm{d}}$ \\
\hline 4 & 207 & $4.2 \pm 0.2^{\mathrm{b}}$ & $4.9 \pm 0.2$ & $4.5 \pm 0.2^{b c}$ & $5.1 \pm 0.2$ & $5.1 \pm 0.2^{\mathrm{ab}}$ & $6.0 \pm 0.1$ & $6.1 \pm 0.2^{\mathrm{ab}}$ & $5.6 \pm 0.2^{\mathrm{c}}$ \\
\hline 5 & 180 & $4.6 \pm 0.2^{\mathrm{ab}}$ & $4.5 \pm 0.2$ & $4.5 \pm 0.2^{\mathrm{bc}}$ & $4.9 \pm 0.2$ & $4.6 \pm 0.2^{c}$ & $6.0 \pm 0.1$ & $6.0 \pm 0.2^{\mathrm{ab}}$ & $5.6 \pm 0.2^{b c}$ \\
\hline 6 & 96 & $4.6 \pm 0.3^{\mathrm{ab}}$ & $4.8 \pm 0.3$ & $4.2 \pm 0.2^{\mathrm{c}}$ & $5.0 \pm 0.3$ & $5.2 \pm 0.2^{\mathrm{ab}}$ & $6.2 \pm 0.2$ & $6.2 \pm 0.2^{\mathrm{a}}$ & $5.7 \pm 0.2^{\mathrm{ab}}$ \\
\hline $\begin{array}{l}\text { Season at time of } \\
\text { classification }\end{array}$ & & $* *$ & ns & $* *$ & $* *$ & $* *$ & ns & $* *$ & $* *$ \\
\hline 1 & 366 & $4.8 \pm 0.2^{\mathrm{a}}$ & $4.7 \pm 0.2$ & $4.7 \pm 0.2^{b}$ & $5.5 \pm 0.2^{\mathrm{a}}$ & $5.2 \pm 0.2^{\mathrm{b}}$ & $6.0 \pm 0.1$ & $6.1 \pm 0.1^{\mathrm{a}}$ & $6.2 \pm 0.1^{\mathrm{a}}$ \\
\hline 2 & 243 & $5.1 \pm 0.3^{\mathrm{a}}$ & $5.3 \pm 0.3$ & $5.5 \pm 0.2^{\mathrm{a}}$ & $5.1 \pm 0.3^{\mathrm{ab}}$ & $4.5 \pm 0.2^{c}$ & $6.3 \pm 0.2$ & $5.9 \pm 0.2^{\mathrm{a}}$ & $5.2 \pm 0.2^{\mathrm{b}}$ \\
\hline 3 & 33 & $2.7 \pm 0.4^{\mathrm{c}}$ & $4.6 \pm 0.4$ & $3.7 \pm 0.3^{c}$ & $5.1 \pm 0.3^{\mathrm{ab}}$ & $4.7 \pm 0.2^{\mathrm{bc}}$ & $5.9 \pm 0.2$ & $5.5 \pm 0.3^{b}$ & $5.2 \pm 0.3^{b}$ \\
\hline 4 & 255 & $4.4 \pm 0.2^{\mathrm{b}}$ & $4.6 \pm 0.2$ & $4.5 \pm 0.2^{b}$ & $4.7 \pm 0.2^{\mathrm{b}}$ & $5.7 \pm 0.2^{\mathrm{a}}$ & $5.9 \pm 0.1$ & $6.3 \pm 0.2^{\mathrm{a}}$ & $5.6 \pm 0.2^{b}$ \\
\hline Classifier & & ns & ns & ns & ns & $*$ & $* *$ & ns & ns \\
\hline 1 & 299 & $4.3 \pm 0.2$ & $4.8 \pm 0.2$ & $4.6 \pm 0.2$ & $5.1 \pm 0.2$ & $4.9 \pm 0.2^{b}$ & $5.9 \pm 0.1^{\mathrm{b}}$ & $5.9 \pm 0.1$ & $5.4 \pm 0.2$ \\
\hline 2 & 299 & $4.2 \pm 0.2$ & $4.8 \pm 0.2$ & $4.6 \pm 0.2$ & $5.2 \pm 0.2$ & $4.9 \pm 0.2^{b}$ & $6.2 \pm 0.1^{\mathrm{a}}$ & $6.0 \pm 0.1$ & $5.6 \pm 0.2$ \\
\hline 3 & 299 & $4.2 \pm 0.2$ & $4.7 \pm 0.2$ & $4.6 \pm 0.2$ & $5.0 \pm 0.2$ & $5.2 \pm 0.2^{\mathrm{a}}$ & $6.0 \pm 0.1^{\mathrm{b}}$ & $5.9 \pm 0.1$ & $5.6 \pm 0.2$ \\
\hline \multicolumn{10}{|l|}{$\begin{array}{l}\text { Age at time of } \\
\text { classification }\end{array}$} \\
\hline Linear & & ns & ns & ns & $*$ & ns & ns & $* *$ & $*$ \\
\hline $\mathrm{b}_{1}$ & & -0.098 & -0.100 & 0.030 & -0.110 & 0.233 & -0.063 & -0.117 & -0.005 \\
\hline Quadratic & & ns & ns & ns & ns & $*$ & ns & $* *$ & ns \\
\hline $\mathrm{b}_{2}$ & & 0.001 & 0.001 & 0.000 & 0.001 & -0.003 & 0.001 & 0.001 & 0.000 \\
\hline
\end{tabular}

$* *, \mathrm{P}<0.01 ; *, \mathrm{P}<0.05 ; \mathrm{ns}$, non-significant

Least-squares means with their standard errors and level of significance of type traits of the dairy cows for several stages of the lactation are presented in Table 2 and 3. Results of the statistical analysis revealed that stage of lactation resulted in significant effect on the large number of linear traits, such as chest width, body depth, angularity, rear leg side view, rump angle, rump width, fore udder attachment, rear udder attachment height, teat placement side view, suspensory ligament, udder depth $(\mathrm{P}<0.01)$ and rear leg rear view $(\mathrm{P}<0.05)$. Significant effects of the stage of lactation for most of traits in current study were in consensus to the results of Esteves et al (2004) in Brazilian Holstein. Similarly, Khan \& Khan (2015) also reported that stage of lactation was significant source of variation for several linear traits, for instance, body depth, angularity, rump width and dewlap surface area, rear legs set, rear udder height, udder depth, fore teat length and rear udder width, chest width $(\mathrm{P}<0.001)$, central ligament $(\mathrm{P}<0.05)$. Stage of lactation effect on rump width, rear udder height and udder depth in current research was in accordance with results of Dahiya (2005a). Additionally, Angelova (2006) reported statistically significant effect of the lactation stage on chest width, angularity, udder depth and central ligament in Bulgarian Brown cattle. As for this study, similar results were pointed out by 
Petkov \& Stoyanova (2006) who studied the impact of the stage of lactation on udder traits and established significant effects on fore udder attachment and suspensory ligament.

Results of the current study regarding change in linear score with advancement in stage of lactation for chest width was in consensus to findings of Marinov et al (2015) where chest width score increased with advancing stage of lactation. Significant stage of lactation effects for fore udder attachment, teat placement side view, teat placement rear view rump angle, body depth, suspensory ligament, rump width, and rear udder attachment height were compatible with findings of Mazza et al (2013). Significant stage of lactation effects for rump width, rear udder attachment height and udder depth in the present study were in agreement with those reported by Dahiya (2005b) for Sahiwal cows. Significant effect of stage of lactation on udder depth in current study was also in harmony with findings of Viji et al (1990). Stage of lactation effect on chest width, central ligament and udder depth were concordant with results of Dahiya (2005a) for Hariana cattle.

Least-squares means along with their standard errors and level of significance of linear type traits in lactating Simmental cows for different classifiers are given in Table 2 and 3. The analysis of variance revealed that the effects of classifiers on all type traits were not statistically significant except for chest width, body depth, teat length, teat placement side view and angularity. In other words, classifiers did not cause significant variations on most of linear type traits, and the result might be attributed to the employing expert classifiers in the present study for the linear type traits assessment. The finding was also in agreement with result of a research reported by Yanar (1999).

Least-squares means along with standard errors and level of significance of linear type traits for different seasons at time of classification are presented in Table 2 and 3. Significant influence of season at time of classification for chest width, body depth, angularity, foot angle, rear leg side view, rear leg rear view, rump width, fore udder attachment, rear udder attachment height, teat placement rear view, teat placement side view, suspensory ligament and udder depth was observed in present study. Significant effect of season at time of classification for rear legs rear view and foot angle as obtained in for this study was also reported for Nili Ravi Buffaloes by Mirza et al (2015).

Linear effect of age at time of classification was not significant for all type traits except for foot angle, rump angle, rump width, teat placement rear view, suspensory ligament and udder depth (Table 2 and 3). Dubey et al (2014) reported significant effect of age at time of classification on foot angle and udder depth; Khan \& Khan (2015) revealed linear effects of age at time of classification on the rump width and udder depth in Sahiwal cattle. Their findings were in consensus to findings of current study. Significant decrease in linear type score of udder depth with age could be attributed to more milk production and development of udder with age.

Estimated phenotypic correlations among linear type traits are given in Table 4. In general, the correlation values were in between lower and medium range, and most of the correlations were less than 0.20 . Similar results were already reported by Duru et al (2012) and Khan \& Khan (2016). The strongest positive phenotypic correlations ( $\mathrm{r}=0.43$ ) were estimated between fore udder attachment and udder depth. The result was in harmony with finding of Liu et al (2014) who reported the strongest correlation value $(\mathrm{r}=0.40)$ between same type traits of Holstein Friesian cows in China. Khan et al (2008) also estimated significant phenotypic correlation $(r=0.29)$ between fore udder attachment and udder depth. Phenotypic correlations with negative sign calculated between body depth and angularity were also reported by Khan et al (2008) which was in accordance with finding of the current study. Correlation between fore udder attachment and teat placement rear view in this study was comparable to findings of Nemcova et al (2011) (r=0.13) and Tapki \& Guzey (2013) $(\mathrm{r}=0.22)$. On the other hand, higher than current study estimates were reported by Berry et al (2004) ( $\mathrm{r}=$ 0.28), and Khan et al (2008) $(r=0.38)$. Similar to the finding of Nemcova et al (2011), correlation between rear udder height and rear udder width in the present study was statistically significant and was in positive direction.

Phenotypic correlations between fore teat length and udder depth were found to be negative and lower in magnitude. These results are in agreement with findings of Nemcova et al (2011) $(\mathrm{r}=-0.01)$ and Tapki \& Guzey (2013) (r= -0.06). Significant negative correlations between chest width and udder depth reported by Yanar (1999), Berry et al (2004) and Nemcova et al (2011) were comparable to results of the present study. Similarly, negative and significant estimates between body depth and udder depth were reported by Berry et al (2004) $(r=-0.20)$, Khan et al (2008) ( $r=-0.44)$, Nemcova et al (2011) $(r=-0.23)$, Duru et al (2012) $(r=-0.32)$, and these findings were in harmony with result of the current study. 
Table 4- Phenotypic correlations and standard errors among the linear type traits

\begin{tabular}{|c|c|c|c|c|c|c|c|c|c|c|c|c|c|c|c|c|c|}
\hline Traits & & l & 2 & 3 & 4 & 5 & 6 & 7 & 8 & 9 & 10 & 11 & 12 & 13 & 14 & 15 & 16 \\
\hline Chest width & (1) & & $0.24^{* *}$ & $-0.17^{* *}$ & -0.02 & 0.00 & -0.00 & $0.07^{*}$ & 0.05 & $-0.09 *$ & $0.08^{*}$ & -0.04 & -0.05 & 0.03 & -0.03 & -0.02 & $-0.19^{* *}$ \\
\hline Body depth & (2) & 0.03 & & $-0.40^{* *}$ & -0.03 & $0.10^{* *}$ & $0.08^{*}$ & 0.02 & $0.07^{*}$ & $-0.18^{* *}$ & 0.04 & $-0.14^{* *}$ & -0.05 & $0.08^{*}$ & $0.09 * *$ & $0.09^{*}$ & $-0.24^{* *}$ \\
\hline Angularity & (3) & 0.03 & 0.03 & & 0.02 & $-0.12^{* *}$ & -0.06 & $-0.12^{* *}$ & $-0.14^{* *}$ & -0.05 & -0.06 & $0.11^{* *}$ & -0.05 & $0.09 * *$ & 0.02 & 0.05 & -0.01 \\
\hline Foot angle & (4) & 0.03 & 0.03 & 0.03 & & $-0.14^{* *}$ & 0.06 & 0.05 & $0.08^{*}$ & -0.01 & $-0.10^{* *}$ & $0.09^{* *}$ & $-0.08 *$ & 0.04 & 0.01 & 0.00 & $0.12^{* *}$ \\
\hline Rear leg (side view) & (5) & 0.03 & 0.03 & 0.03 & 0.03 & & $0.10^{* *}$ & $0.09^{*}$ & $0.08^{*}$ & $0.07^{*}$ & -0.01 & 0.02 & $0.10^{* *}$ & -0.05 & 0.02 & 0.03 & $0.14^{* *}$ \\
\hline Rear leg (rear view) & (6) & 0.03 & 0.03 & 0.03 & 0.03 & 0.03 & & -0.04 & $0.11^{* *}$ & -0.05 & 0.03 & 0.04 & 0.03 & $0.17^{* *}$ & -0.01 & $0.08^{*}$ & -0.03 \\
\hline Rump angle & (7) & 0.03 & 0.03 & 0.03 & 0.03 & 0.03 & 0.03 & & 0.02 & $-0.11^{* *}$ & $-0.13^{* *}$ & 0.03 & $-0.13^{* *}$ & -0.03 & -0.02 & $-0.16^{* *}$ & 0.06 \\
\hline Rump width & (8) & 0.03 & 0.03 & 0.03 & 0.03 & 0.03 & 0.03 & 0.03 & & -0.01 & 0.04 & -0.05 & 0.02 & $0.13^{* *}$ & -0.01 & -0.03 & 0.02 \\
\hline Fore udder attachment & (9) & 0.03 & 0.03 & 0.03 & 0.03 & 0.03 & 0.03 & 0.03 & 0.03 & & 0.06 & $0.07^{*}$ & $0.16^{* *}$ & $-0.38^{* *}$ & 0.04 & $-0.13^{* *}$ & $0.43^{* *}$ \\
\hline Rear udder attachment width & (10) & 0.03 & 0.03 & 0.03 & 0.03 & 0.03 & 0.03 & 0.03 & 0.03 & 0.03 & & $0.09 * *$ & 0.01 & 0.03 & $0.18^{* *}$ & 0.02 & $-0.23^{* *}$ \\
\hline Rear udder attachment height & (11) & 0.03 & 0.03 & 0.03 & 0.03 & 0.03 & 0.03 & 0.03 & 0.03 & 0.03 & 0.03 & & -0.04 & -0.07 & $0.09^{* *}$ & $0.07^{*}$ & $0.07^{*}$ \\
\hline Teat placement (rear view) & (12) & 0.03 & 0.03 & 0.03 & 0.03 & 0.03 & 0.03 & 0.03 & 0.03 & 0.03 & 0.03 & 0.03 & & -0.00 & $-0.19^{* *}$ & $0.10^{* *}$ & $0.14^{* *}$ \\
\hline Teat placement (side view) & (13) & 0.03 & 0.03 & 0.03 & 0.03 & 0.03 & 0.03 & 0.03 & 0.03 & 0.03 & 0.03 & 0.03 & 0.03 & & $-0.13^{* *}$ & $0.11^{* *}$ & $-0.32^{* *}$ \\
\hline Teat length & (14) & 0.03 & 0.03 & 0.03 & 0.03 & 0.03 & 0.03 & 0.03 & 0.03 & 0.03 & 0.03 & 0.03 & 0.03 & 0.03 & & -0.02 & $-0.09 * *$ \\
\hline Suspensory ligament & (15) & 0.03 & 0.03 & 0.03 & 0.03 & 0.03 & 0.03 & 0.03 & 0.03 & 0.03 & 0.03 & 0.03 & 0.03 & 0.03 & 0.03 & & $-0.11^{* *}$ \\
\hline Udder depth & (16) & 0.03 & 0.03 & 0.03 & 0.03 & 0.03 & 0.03 & 0.03 & 0.03 & 0.03 & 0.03 & 0.03 & 0.03 & 0.03 & 0.03 & 0.03 & \\
\hline
\end{tabular}

Note: Phenotypic correlations (above diagonal) and standard errors below diagonal; ${ }^{* *}, \mathrm{P}<0.01 ; *, \mathrm{P}<0.05$

\section{Conclusions}

Overall results of the study revealed considerable effects of the non-genetic factors on linear type traits of Simmental cows. Parity, season at time of classification and stage of lactation were especially important sources of variation for most of type traits. Linear and quadratic effects of age at time of classification were also significant for some type traits. Phenotypic correlations among linear type traits were in low to medium range. Genetic evaluation of Simmental cows for these traits needs to be based on models that take effects of these environmental factors into account in order to obtain unbiased results. Therefore, adjustment for the non-genetic factors will decrease known environmental differences among animals and increase accuracy of the breeding values.

\section{References}

Alphonsus C, Akpa G N, Mukasa C, Rekwot P I \& Barje P P (2011). Genetic evaluation of linear udder and body conformation traits in Bunaji cows. Animal Research International 8(1): 1366-1374

Angelova T (2006). Study for opportunities to optimize the selection of Brown cattle in Bulgaria. Ph.D. Thesis, Institute of Agriculture (Unpublished), Stara Zagora, Bulgaria

Berry D P, Buckley F, Dillon P, Evans R D \& Veerkamp R F (2004). Genetic relationships among linear type traits, milk yield, body weight, fertility and somatic cell count in primiparous dairy cows. Irish Journal of Agricultural and Food Research 43(2): 161176

Bohlouli M, Alijani S \& Varposhti M R (2015). Genetic relationships among linear type traits and milk production traits of Holstein dairy cattle. Annals of Animal Science 15(4): 903-917 
Dahiya S P (2005a). Linear functional type traits for reproductive efficiency in Hariana cows. The Indian Journal of Animal Sciences 75(5): 524-527

Dahiya S P (2005b). Appraisal of linear type traits for reproductive efficiency in Sahiwal cows. The Indian Journal of Animal Sciences 75(8): 945-948

Dubey A (2010). Studies on linear type traits in Sahiwal. M.V.Sc. Thesis, Indira Gandhi Agricultural University (Unpublished), Raipur, India

Dubey A, Mishra S \& Khune V (2014). Appraisal of linear type traits in Sahiwal cattle. Indian Journal of Animal Research 48(3): 258-261

Duru S, Kumlu S \& Tuncel E (2012). Estimation of variance components and genetic parameters for type traits and milk yield in Holstein cattle. Turkish Journal of Veterinary and Animal Sciences 36(6): 585-591

Essien A \& Adesope O M (2003). Linear body measurements of N'dama calves at 12 months in a South Western zone of Nigeria. Livestock Research for Rural Development 15(4): 34

Esteves A M C, Bergmann J A G, Durães M C, Costa C N \& Silva H M (2004). Study of environmental effects on linear type traits in Brazilian Holstein. Arquivo Brasileiro de Medicina Veterinária e Zootecnia 56(4): 522-528

Harris R A (2015). Phenotypic correlations between linear type conformation traits, production and fertility in a once-a-day milk dairy cattle herd. M.V.Sc. Thesis. Massey University (Unpublished), Palmerston Norton, New Zealand

ICAR (2014). ICAR Recording Guidelines. International Comittee for Animal Recording. Icar conformation working group. Approved by the General Assembly held in Berlin on May 2014, Germany

Javed K, Mirza R H, Abdullah M, Naseer T \& Akhtar P M (2013). Studies on linear type traits and morphometric measurements in Nili Ravi buffaloes of Pakistan. Buffalo Bulletin 32(2): 780-783

Juozaitiene V, Juozaitis A \& Micikeviciene R (2006). Relationship between somatic cell count and milk production or morphological traits of udder in Black-and-White cows. Turkish Journal of Veterinary and Animal Sciences 30(1): 47-51

Khan M A \& Khan M S (2015). Non-genetic factors affecting linear type traits in Sahiwal cows. Journal of Animal and Plant Science 25(1): 29-36

Khan M A \& Khan M S (2016). Genetic and phenotypic correlations between linear type traits and milk yield in Sahiwal cows. Pakistan Journal of Agricultural Sciences 53(2): 483-489

Khan M A, Khan M S \& Iqbal A (2008). Genetic and phenotypic correlations among linear type traits in Sahiwal cows. Pakistan Journal of Agricultural Sciences 45(2): 268-274

Liu S, Tan H, Yang L \& Yi J (2014). Genetic parameter estimates for selected type traits and milk production traits of Holstein cattle in southern China. Turkish Journal of Veterinary and Animal Sciences 38(5): 552-556

Marinov I, Penev T \& Gergovska Z (2015). Factors affecting linear type traits in black-and-white cows. International Journal of Current Microbiology and Applied Sciences 4(10): 374-383

Mazza S, Sartori C, Berry D \& Mantovani R (2013). Factors affecting linear type traits of Valdostana cattle. Agriculturae Conspectus Scientificus 78(3): 207-211

Mirza R H, Javed K, Abdullah M, Pasha T N \& Akhtar M (2015). Heritability estimates of some linear type traits in nili ravi buffaloes. JAPS, Journal of Animal and Plant Sciences 25(1): 23-28

Nemcova E, Stipkova M \& Zavadilova L (2011). Genetic parameters for linear type traits in Czech Holstein cattle. Czech Journal of Animal Science 56(4): 157-162

Parveen K (2008). Genetic studies on body measurements and their association with age and production performance in Sahiwal. M.V.Sc. Thesis, Indira Gandhi Agricultural University (Unpublished), Raipur, India

Petkov P \& Stoyanova R (2006). Study of some linear type traits in relation with cow age and period of lactation. Animal Science XLIII(1): 22-25 
Schneider M P, Dürr J W, Cue R I \& Monardes H G (2003). Impact of type traits on functional herd life of Quebec Holsteins assessed by survival analysis. Journal of Dairy Science 86(12): 4083-4089

SPSS (2004). SPSS for Windows Release 13.0, Chicago, IL. USA

Tapki I \& Guzey Y Z (2013). Genetic and phenotypic correlations between linear type traits and milk production yields of Turkish Holstein dairy cows. Greener Journal of Agricultural Sciences 3(11): 755-761

Tuzemen N, Yanar M \& Akbulut Ö (2013). Animal Improvement. Ataturk University College of Agriculture Public. Num.: 230 . A. U. Publishing Office, Erzurum, Turkey

Veerkamp R F, Gerritsen C L M, Koenen E P C, Hamoen A \& De Jong G (2002). Evaluation of classifiers that score linear type traits and body condition score using common sires. Journal of Dairy Science 85(4): 976-983

Viji P K, Balain D S, George M \& Vinayak A K (1990). Linear type traits and their influence on milk production in Tharparkar cattle. Indian Journal of Animal Sciences 60(7): 845-852

Yanar M (1999). Factors affecting linear type traits for Holstein-Friesian cattle reared in Eastern Turkey. Indian Journal of Animal Sciences 69(4): 260-262

Zavadilova L \& Stipkova M (2012). Genetic correlations between longevity and conformation traits in the Czech Holstein population. Czech Journal of Animal Science 57(3): 125-136 